\title{
Diálogos entre o Velmo e o Novo Mundo: Robson Crusoe e Sexta-Feira*
}

\author{
Maria Ligia Coelho Prado** \\ ecprado@usp.br
}

Resumo: Em 1719, o romance de Daniel Defoe, Vida e Aventuras de Robinson Crusoe, teve inúmeras edições e se transformou em grande sucesso editorial. Com o passar do tempo, as edições foram sendo modificadas, assim como as construções imagéticas dos personagens principais, Robinson Crusoe e Sexta-feira. Este artigo pretende colocar em debate tais interpretações, considerando que a narrativa de Defoe e suas incontáveis apropriações evocam uma relação naturalizada entre colonizador e colonizado.

Palavras-Chave: Crusoe, Sexta-feira, Defoe, civilização, barbárie.

O romance de Daniel Defoe, Vida e Aventuras de Robinson Crusoe, publicado em 1719, consagrou seu autor e se transformou em enorme e imediato êxito editorial ${ }^{1}$. Suas incontáveis edições atravessaram os séculos, fazendo com que o título permanecesse nos catálogos das editoras até o presente. O crítico Ian Watts o considerou o primeiro romance moderno em língua inglesa (WATT, 1957). O interesse por essa obra pode ser medido pela vasta e notável produção intelectual por ela suscitada, incluindo autores tão diversos quanto James Joyce e Karl Marx, cujos olhares circunscreveram aspectos específicos e produziram reflexões originais. Neste artigo, pretendo fazer um recorte particular, colocando a famosa narrativa do náufrago na ilha deserta em um lugar privilegiado dentro do universo dos diálogos culturais entre o Velho e o Novo Mundo.

Defoe (1660-1731) se baseou na história real do marinheiro escocês, AlexandreSelkirk (1676-1721), cujo navio bucaneiro navegava pelo Atlântico sul em busca das riquezas transportadas por navios da Coroa espanhola. Depois de um ataque "bem sucedido", do qual resultou um belo botim, o navio sofreu avarias. Selkirk desentendeu-se com seu comandante, que não queria consertar o navio

\footnotetext{
* Agradeço a Gabriela Pellegrino Soares que generosamente trouxe da França e da Inglaterra o material fundamental para a realização deste artigo.

** Professora do Departamento de História da Universidade de São Paulo.
} 
antes de voltar à Europa pelo Cabo Horn. O episódio culminou com a decisão do capitão de castigá-lo, desembarcando-o na ilha Mas a Tierra, no arquipélago Juan Fernández, na costa do Chile². Isso ocorreu em 1704 e Selkirk lá viveu completamente sozinho por quatro anos até ser resgatado por outro navio britânico que o levou de volta à Europa. Tem-se repetido que as aventuras de Selkirk se constituem na principal inspiração para o romance do escritor inglês.

Defoe estava destinado a ser ministro presbiteriano, mas abandonou os estudos e encaminhou-se para o ramo do comércio e das finanças. Porém, os negócios não prosperaram e ele afundou-se em dívidas. Por essa razão, foi preso pela primeira vez em 1692. Viajou pela Grã-Bretanha e pela Europa ocidental sempre em função de atividades comerciais que não frutificaram. Simultaneamente, escrevia artigos e panfletos que discutiam questões de ordem política. Suas posições partidárias oscilaram, ora apoiando os whigs, ora os tories. Simpatizante da Revolução de 1688, escreveu mais tarde, em 1697, um poema em defesa do rei Guilherme III, The true-born Englisman. Sua fama de rebelde e inconstante contribuiu para uma nova prisão, em 1703, desta vez, acusado de ter escrito um panfleto desrespeitosoà Igreja Anglicana, The shortest way with the Dissenters. Foi exposto no pelourinho por três dias (Charing Cross Pillory - Figura 1) e enviado em seguida para a prisão (Newgate Prison), onde passou alguns meses.

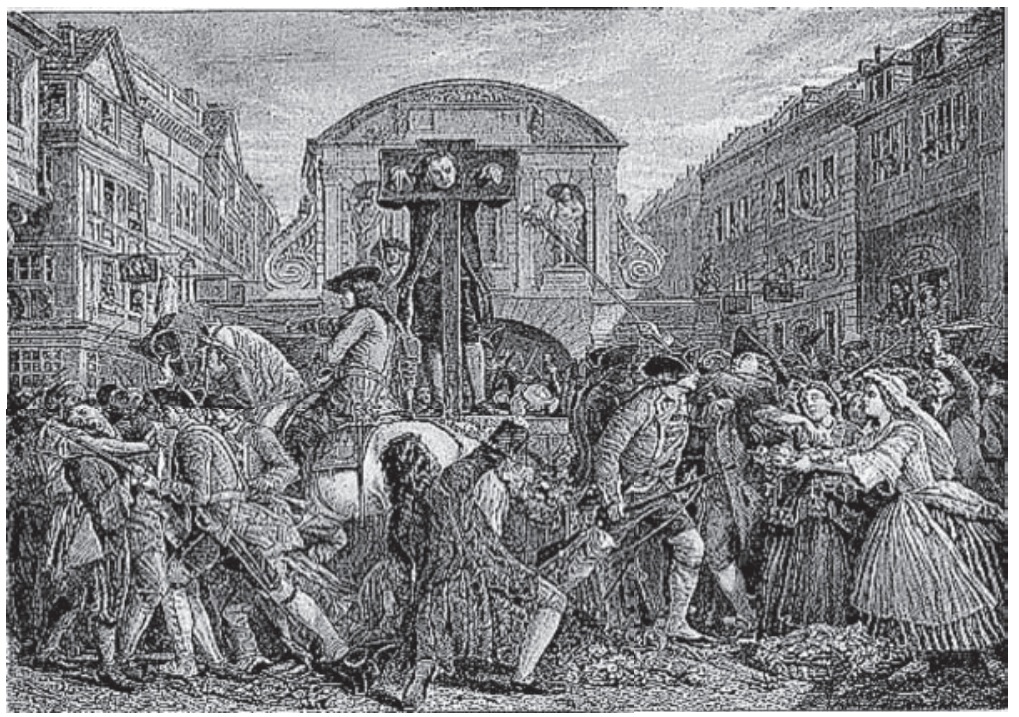

Figura 1: Daniel Defoe exposto no pelourinho, Charing Cross Pillory (1703).

Fonte: $<$ http://upload.wikimedia.org/wikipedia/commons/5/5c/Daniel_Defoe_by_James_Charles_Armytage.jpg >. Acesso em: 12 mar. 2010. 
Já maduro, quase aos sessenta anos, escreveu seu primeiro romance, Robinson Crusoe, que lhe deu notoriedade, mas não resolveu seus problemas financeiros. Produziu entre 1719 e 1724 outros sete romances, o mais lembrado deles, Moll Flanders (1722), que narra a história de uma prostituta sem escrúpulos. Morreu em 1731, só e endividado.

A história de Robinson Crusoe não interessou a diversos editores para os quais Defoe mostrou os originais. Finalmente, em maio de 1719, William Taylor decidiu-se por sua publicação. O sucesso foi tão inesperado quanto impressionante, havendo seis impressões em apenas quatro meses, num total aproximado de 80.000 exemplares vendidos. Um bom termômetro para medir o êxito do texto está na proliferação de edições piratas do livro, assim como na iniciativa precoce de publicações resumidas, como a do editor T. Cox que, em julho de 1719, já publicava uma edição mais barata, com 100 páginas a menos. Também as imitações se constituem em outra manifestação da popularidade da obra de Defoe; no mesmo ano de 1719, publicou-se as Memórias autênticas do Capitão Falconer, emulação da história de Robinson. Com o passar das edições, a narrativa foi se reduzindo ao episódio do náufrago na ilha deserta, deixando de lado a primeira parte e toda a discussão sobre questões morais e religiosas ${ }^{3}$.

O livro também foi rapidamente traduzido para diversas línguas. Para nos determos na França, a primeira tradução, à qual muitas se seguiram, é de 1720 (DELMAS, 1995). Vale observar que já no século XVIII, ocorreram adaptações do texto para leitura da juventude 4 . Em 1766, apareceu a versão elaborada por M. Feutry, preceptor dos filhos do marquês de Puységur. Homem da Ilustração, Feutry condenava a escravidão e a servidão, pretendendo transmitir uma lição de moral a seus alunos. Talvez Feutry tenha se inspirado em Rousseau para quem Robinson Crusoe deveria ser a primeira leitura de seu famoso Emílio (1762). Considerando que o livro era "o mais curioso tratado de educação natural", Rousseau, entendia que o texto proporcionaria instrução e diversão a Emílio. Na França, houve outras adaptações para a juventude com ênfase nas questões educativas e morais do texto, tendo até mesmo sido incorporado como livro de texto nas escolas (DELMAS; MEUNIER, 1995).

Todos conhecem a história do náufrago Robinson Crusoe, que viveu por 28 anos numa ilha deserta, desenvolvendo suas potencialidades individuais em confronto com a natureza e encontrando os meios para sobreviver a partir de suas habilidades e conhecimentos. Como afirma James Joyce (1964, p. 24), de náufrago na ilha, com uma faca e um cachimbo no bolso, Robinson se transforma em "arquiteto, carpinteiro, afiador de 
faca, astrônomo, padeiro, construtor de navios, oleiro, agricultor, alfaiate, fazedor de guarda-chuvas e clérigo". Defoe constroi um modelo otimista das possibilidades do domínio do homem sobre a natureza, através do conhecimento racional. Robinson planta, cria cabras, faz uma casa, levanta uma fortaleza para defender-se de supostos inimigos. Com exceção de raros momentos, mantém a lucidez, tomando a razão como sua bússola. A religião lhe é um conforto, lê a Bíblia, reza, busca explicações para os desígnios de Deus. Vive num pequeno mundo organizado, com leis, ordem e uma refletida divisão do tempo.

Muitas vezes, entretanto, passa desapercebido ao leitor o fato de que a fatídica viagem de Crusoe inicia-se no Brasil - onde, depois de muitas aventuras, ele chegara trazido por um capitão português e onde vivia como proprietário de terras - com destino à África, tendo como objetivo determinado a compra de escravos. O naufrágio acontece no mar do Caribe, pois a desembocadura do rio Orenoco é a última referência geográfica indicada pelo autor antes do desastre. Como afirma Peter Hulme em seu Colonial Encounters, ainda que a ilha de Crusoe esteja claramente localizada e que os ameríndios citados por Defoe, incluindo Sexta-feira, sejam sempre apresentados como Caribes, o romance não é pensado como um livro caribenho. É uma fábula puritana, um romance sobre o individualismo econômico, ou simplesmente a história de um homem em uma ilha deserta perdida no oceano, cuja localização carece de importância (HULME, 1986).

Nesse sentido, as ilustrações das primeiras edições de Crusoe não contêm qualquer evidência em termos da flora, fauna ou clima que identifique o lugar como uma ilha do Caribe. No frontispício da primeira edição inglesa de 1719, em desacordo com o clima quente, Robinson aparece descalço, mas vestido de pele de cabras cobrindo todo o corpo. De forma significativa, carrega uma espada à cintura e segura duas armas de fogo. (Figura 2) Essa imagem será repetida à exaustão nas edições seguintes. $\mathrm{Na}$ primeira edição francesa de 1720, ele aparece vestido, com um guarda-sol, uma arma de fogo, um cesto às costas e um serrote à cintura (Figura 3). Mais de um século depois, na edição francesa de 1840, ele é desenhado de forma semelhante com os mesmos apetrechos, mas o guarda-sol desapareceu e ele ganhou umas sandálias (Figura 4). Um século à frente, na edição francesa de 1933, Robinson continua aparelhado com os mesmos emblemas do homem moderno: armas de fogo e ferramentas de trabalho e vestido de maneira inadequada ao clima (Figura 5) ${ }^{5}$. E é desse modo que ele está representado em recente edição brasileira dirigida ao público infantil (Figura 6). 

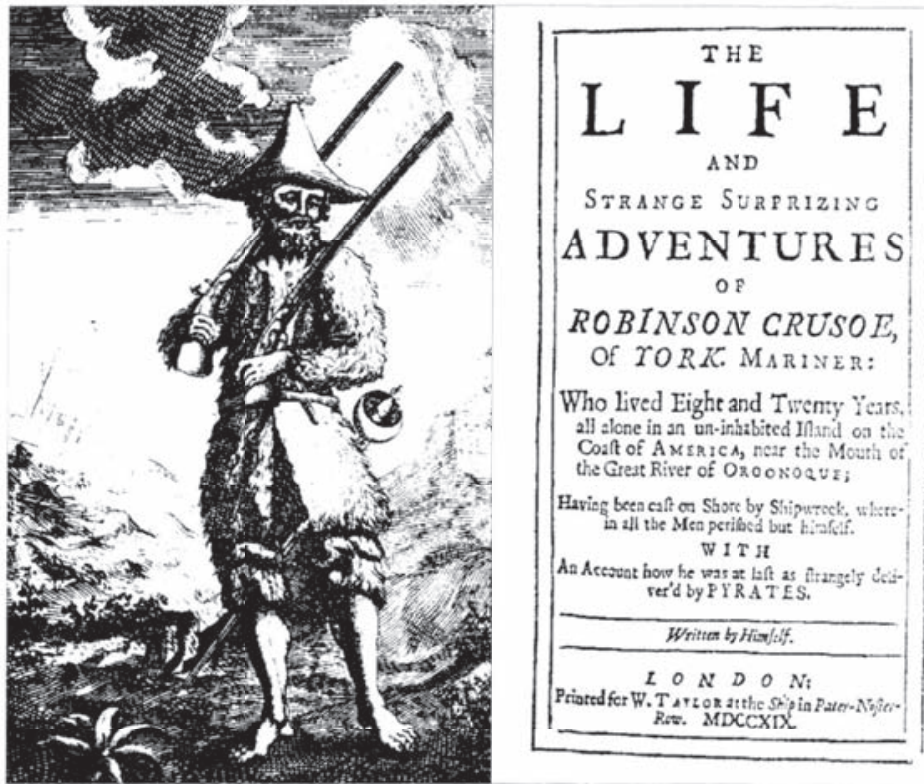

Page de titre et frontispice de l'édition originale - 1719

Figura 2: Robinson Crusoe ilustrado no frontispício da primeira edição inglesa de 1719. Londres: W. Taylor, 1719.

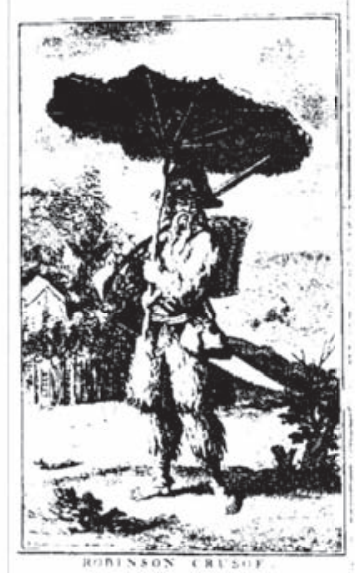

\author{
L A V I E \\ ET LES
}

AVANTURES

SURPRENANTES

D E

ROBINSON CRUSOE,

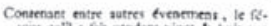

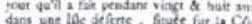

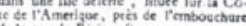

de la grande Riniche Oresteofert

4 towt tait per hai-ater.

TRADUTZ DE EANGZOTE

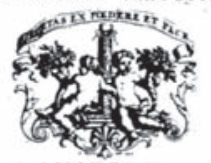

A AMSTERDAM,

Che LHoxour \& CEATH.

MD C $X x$.

Page de titre et frontispice de Bernard Picard

Édition originale de la première traduction française - 1720

Figura 3: Robinson Crusoe na primeira edição francesa de 1720. Ilustração de Bernard Picard. Amsterdam, L'Honoré \& Chatelais, 1720. 


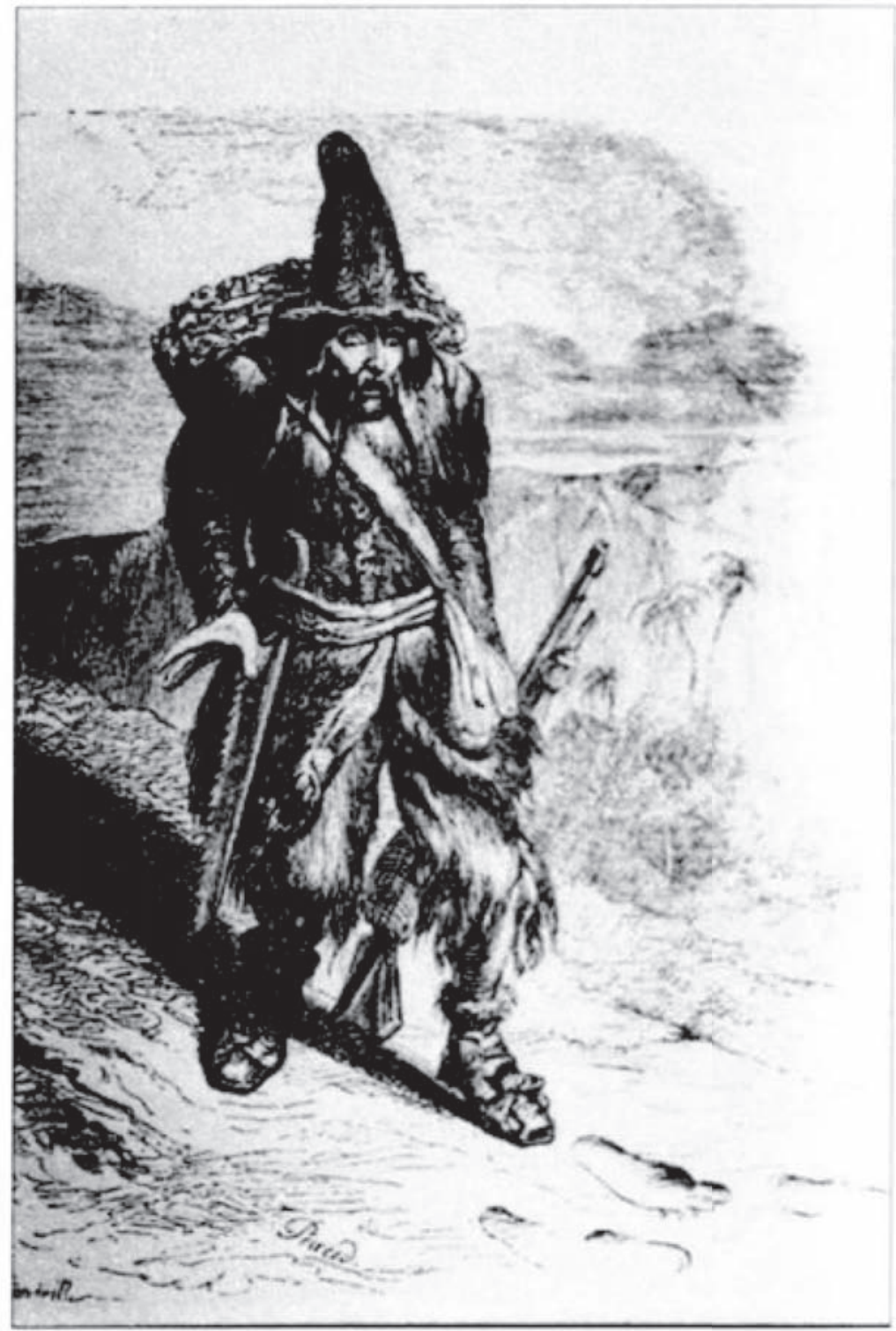

Illustration de Grandville

Ed. Fournier Aîné - 1840

Figura 4: Edição francesa de 1840. Paris: Fournier Aïné, 1840, ilustração de Grandville. 


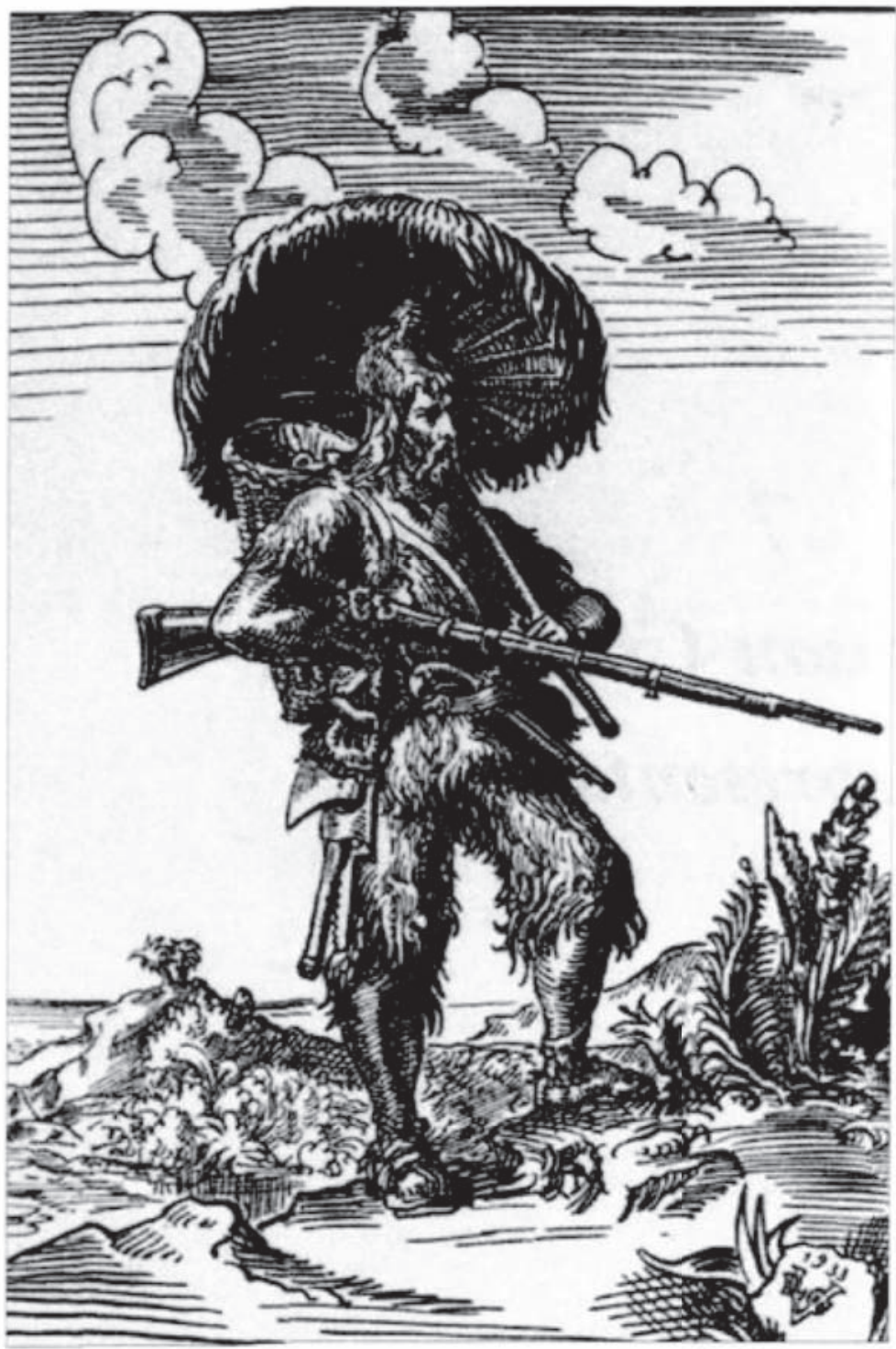

Illustration de Valentin Le Campion Éd. Bovin \& Cie - 1933

Figura 5: Edição francesa de 1933. Paris: Bovin \&Cie., ilustração de Valentin Lê Campion.

Fonte : Delmas e Meunier (1995).

Maria Ligia Coelho Prado. Diálogos entre o Velho e o Novo Mundo: Robinson Crusoe e Sexta-Feira 


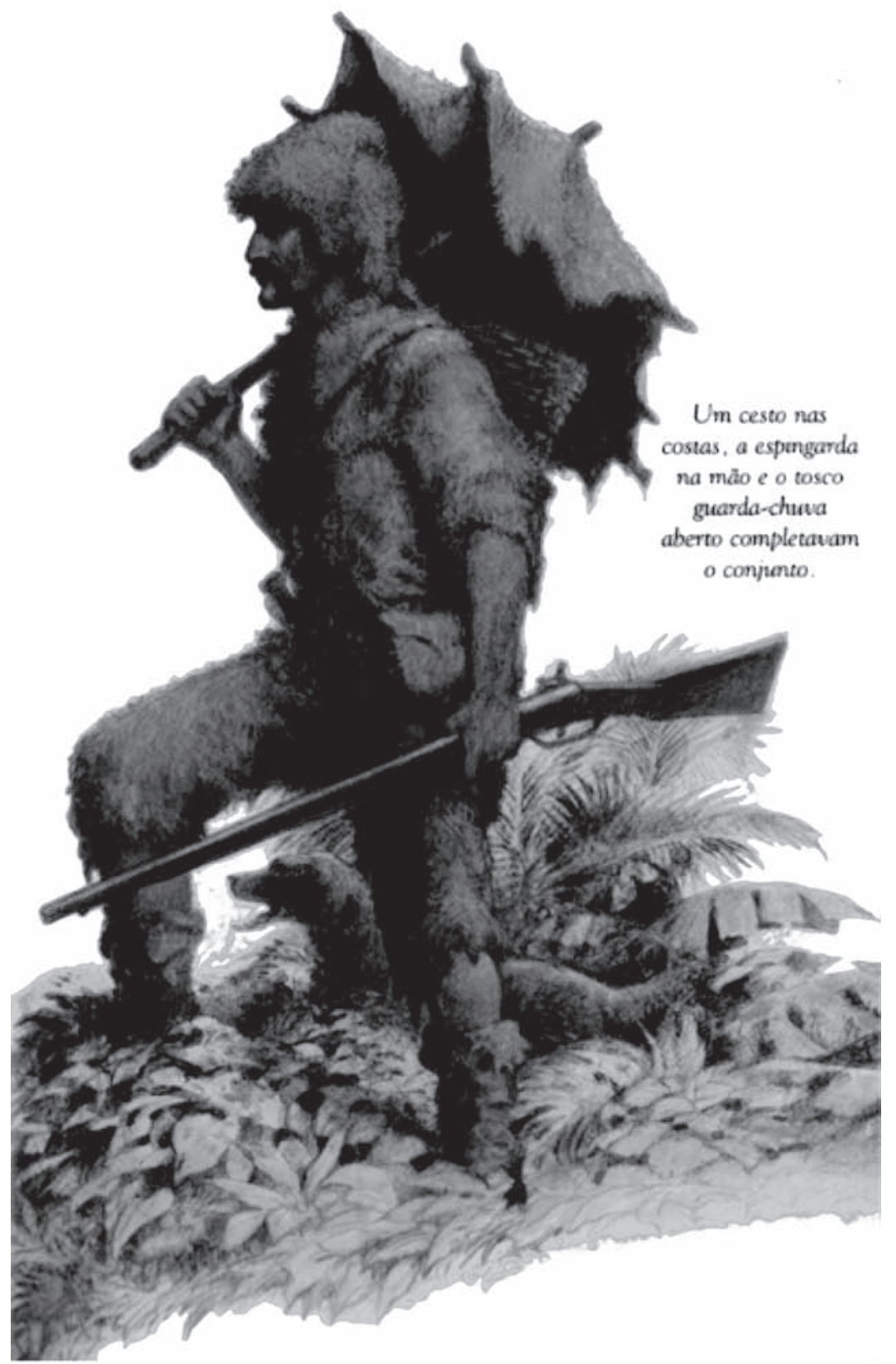

Figura 6: Ilustração da edição brasileira.

Fonte: Crusoe (1999).

Hist.R., Goiânia, v. 15, n. 1, p. 133-157, jan./jun. 2010 
Como afirmei anteriormente, muito se escreveu sobre Robinson Crusoe, propondo questões e interpretações que pretendem desvendar os múltiplos significados da obra. ${ }^{6}$ Referência obrigatória para nós historiadores é o artigo clássico de Christopher Hill (1972), Robinson Crusoe, que pode ser entendido como uma entrada principal para o universo de problemas debatidos referentes à personagem central do romance. $\mathrm{O}$ historiador inglês indica as ambiguidades do comportamento de Robinson na ilha em comparação a um modelo estrito do puritanismo inglês. Em primeiro lugar, Robinson não batiza Sexta-feira, ainda que o considere um cristão; não sabe o que responder a ele, quando este pergunta por que Deus permitiu a existência do demônio. Além disso, enquanto estava na ilha longe do mundo comercial, foram o católico capitão português e o convento brasileiro de agostinianos que cuidaram de suas terras e rendas tão bem quanto a viúva protestante de Londres. Há uma perspectiva de tolerância religiosa, pois ele está bem confortável no Brasil, sob a ordem dos "papistas", e mantém boas relações com os espanhois quando estes chegam à ilha.

Por outro lado, Hill aponta também para os traços típicos de uma visão religiosa presbiteriana. $\mathrm{O}$ ascetismo, a auto-disciplina e o trabalho árduo guiam seu padrão de comportamento. Crusoe acredita que seus infortúnios foram um castigo por sua desobediência ao destino que seu prudente pai lhe havia traçado. Aceitando que Deus usa nossas próprias ações para nos punir, demonstra acreditar na predestinação, de acordo com a tradição calvinista na Inglaterra. Robinson guarda o sétimo dia da semana, como o dia do Senhor, seguind o o imaginado calendário por ele elaborado. Adquire o hábito de pedir a bênção de Deus antes de comer e não pode suportar a ideia da nudez, mesmo estando sozinho na ilha; assim, cobre o corpo inteiramente, como já vimos nas ilustrações iniciais. Na trilha da mesma tradição religiosa, escreve um diário no qual anota as coisas boas e as coisas más que lhe sucedem e que funciona como um balanço espiritual. Também marca seus "lucros" e suas "perdas". Estas anotações são a prova de que a sobrevivência e o final enriquecimento de Crusoe se devem ao trabalho constante e à recusa da perda de tempo. Segundo Hill, no romance, o protestantismo tradicional está acompanhado por uma visão de moralidade nos negócios, na perspectiva do espírito do capitalismo de Weber

Hill também salienta a ausência de mulheres no romance. A única menção ao sexo feminino acontece ao final do livro. De volta à Inglaterra, em um único e curto parágrafo, Robinson afirma: "Fixei-me na minha terra, onde me casei. Tive três filhos, dois meninos e uma menina. Minha mulher 
morreu logo em seguida.” Mais à frente, acompanha-se a associação entre mulher e mercadoria; nosso personagem declara que tinha mandado do Brasil para os novos habitantes da ilha "cinco vacas, um bezerro, porcos..."; na sentença seguinte, acrescenta que também enviara "sete mulheres como domésticas ou companheiras". Hill (1972, p. 20) lembra que Ian Watts entende "de maneira interessante que para Defoe sexo é mais uma mercadoria que uma relação humana".

Defoe cria um final feliz para Crusoe, que volta à Inglaterra acompanhado por seu "fiel escudeiro", Sexta-feira, que o segue de muito bom grado. Em seu país natal, Robinson descobre que se tornara um homem rico, pois o pecúlio que deixara com a honesta viúva inglesa lhe rendera lucro e a venda das terras no Brasil também lhe proporcionara um grande montante de dinheiro. Baseado nas transações econômicas empreendidas por Robinson, que culminam com seu enriquecimento ao final do livro, Stephen Hymer (1972) produz uma inesperada interpretação sobre as práticas de Robinson, desvendando os segredos da acumulação primitiva do capital. Para isso, afirma que quer ir além dos detalhes da história de Robinson para ilustrar a análise de Marx sobre a economia capitalista, especialmente o período da acumulação primitiva que é seu ponto de partida ${ }^{8}$. Esta interpretação de Hymer é um exemplo radical das possibilidades de reflexão sobre o romance, ainda que - como no caso citado - o autor se descole do texto do romance para fazer outras considerações.

A relação entre Robinson e Sexta-feira, imaginada por Defoe, incita a outra ordem de reflexões. Na minha perspectiva, ela pode ser entendida como a construção modelar da "relação bem sucedida" entre o colonizador europeu e o colonizado americano. Como o irlandês James Joyce observou em 1912: "O verdadeiro símbolo da conquista dos britânicos está em Robinson Crusoe. Ele é o verdadeiro protótipo do colonizador britânico, assim como Sexta-feira (o confiante selvagem que chega em um dia infeliz) é o símbolo das raças submetidas" do homem solitário no "deserto" mundo americano é uma reprodução em miniatura da "descoberta" do Novo Mundo pelos europeus e de sua "obra civilizatória".

Na narrativa de Defoe, a relação entre Robinson e Sexta-feira foi naturalizada e surge diante dos olhos do leitor como uma consequência lógica da dinâmica dos encontros humanos assimétricos, aqui protagonizados por representantes do Velho e do Novo Mundo. Se Robinson salvou a vida de Sextafeira, que ia ser devorado num festim canibal, a resposta do índio somente poderia ser a de uma pessoa eternamente grata. Em segundo lugar, como 
sua vida foi salva pela utilização de uma arma de fogo, produto da técnica moderna, Sexta-feira deveria curvar-se diante da superioridade europeia e aceitar seu lugar subordinado. O resultado apresentado por Defoe é, nessa sequência, o de uma relação harmoniosa, na qual as duas partes conhecem seus lugares e não os colocam em dúvida. A submissão de Sexta-feira é relatada nos mínimos detalhes. Robinson dá o nome de Sexta-feira ao índio - referido ao dia em que ele chegou, no imaginado calendário robinsoniano. Mas ele não é considerado digno do batismo. Crusoe ensina-lhe a língua inglesa, porém Sexta-feira jamais será capaz de aprendê-la corretamente, falando de forma trôpega. Sintomaticamente, a primeira palavra ensinada e aprendida é Master. Fornece roupas para vestir sua nudez e coloca-o para dormir do lado de fora de sua cabana, mais precisamente na porta. A roupa, exterioridade palpável da condição de civilizado, faz de Robinson um ser diferenciado do bárbaro índio nu. $\mathrm{O}$ ato de vestir Sexta-feira tem um valor simbólico, pois representa o primeiro passo no seu ritual de passagem da selvageria para a civilização.

Robinson ensina Sexta-feira a plantar, a criar cabras. Com argumentos racionais, explica-lhe que deve abandonar o costume de comer carne humana, advertência também aceita por Sexta-feira. No tratamento dispensado ao caribenho não se coloca a questão da individualidade do "outro". Está fora do universo cultural de Robinson/Defoe perguntar algo sobre as crenças, a língua, os hábitos e os costumes anteriores do índio. Sua vida anterior, na qual deveria ter um nome, é apagada. Sua real existência se inicia no dia do encontro com o homem branco. O encontro estabelece $o$ momento da origem da relação fazendo tábula rasa do passado individual e cultural do índio ${ }^{10}$.

$\mathrm{O}$ momento da chegada de Sexta-feira à ilha aparece sempre nas ilustrações. Numa edição inglesa do século XVIII, Robinson, vestido com as peles de cabra, com uma arma ao ombro e outra apoiada no chão, ar de heroi vencedor, olha em direção a Sexta-feira, totalmente nu, estirado ao chão, beijando-lhe humildemente os pés. A culminância do ato de submissão/dominação está representada pela postura de Sexta-feira que coloca o pé de Robinson sobre sua cabeça (Figura 7) ${ }^{11}$. No começo do século XX, há uma edição brasileira que reproduz exatamente a mesma cena (Figura 8) ${ }^{12}$. Numa edição francesa da década de 1920, a ilustração mantém a mesma moldura: Robinson paramentado e com a arma às costas encena um gesto paternal, estendendo a mão sobre Sexta-feira; este, vestido apenas com uma tanga, de joelhos, faz uma espécie de reverência diante do inglês (Figura 9) ${ }^{13}$. 


\section{ROBINSON CRUSOE}

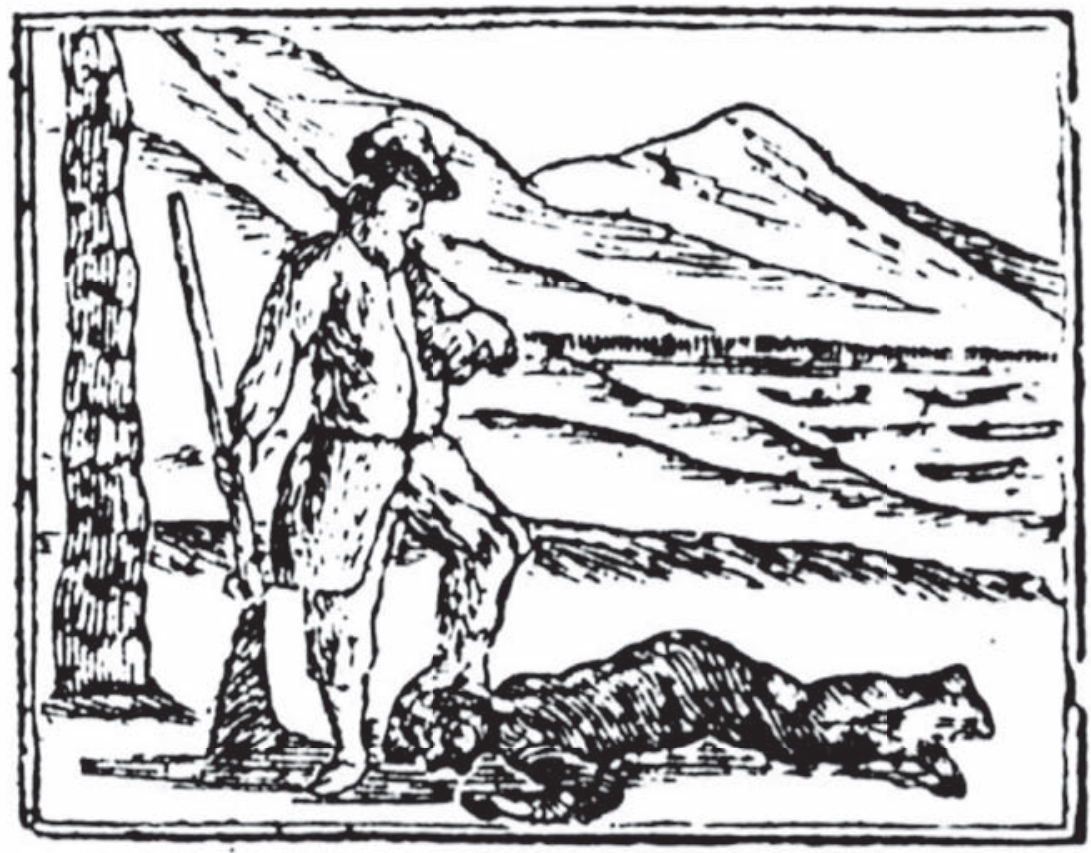

Figura 7: Edição do século XVIII, porém sem data específica, Londres, S. Jewkes (p.75).

Fonte: Opie Collection of Children's Literature, Bodleian Library, Universidade de Oxford. 


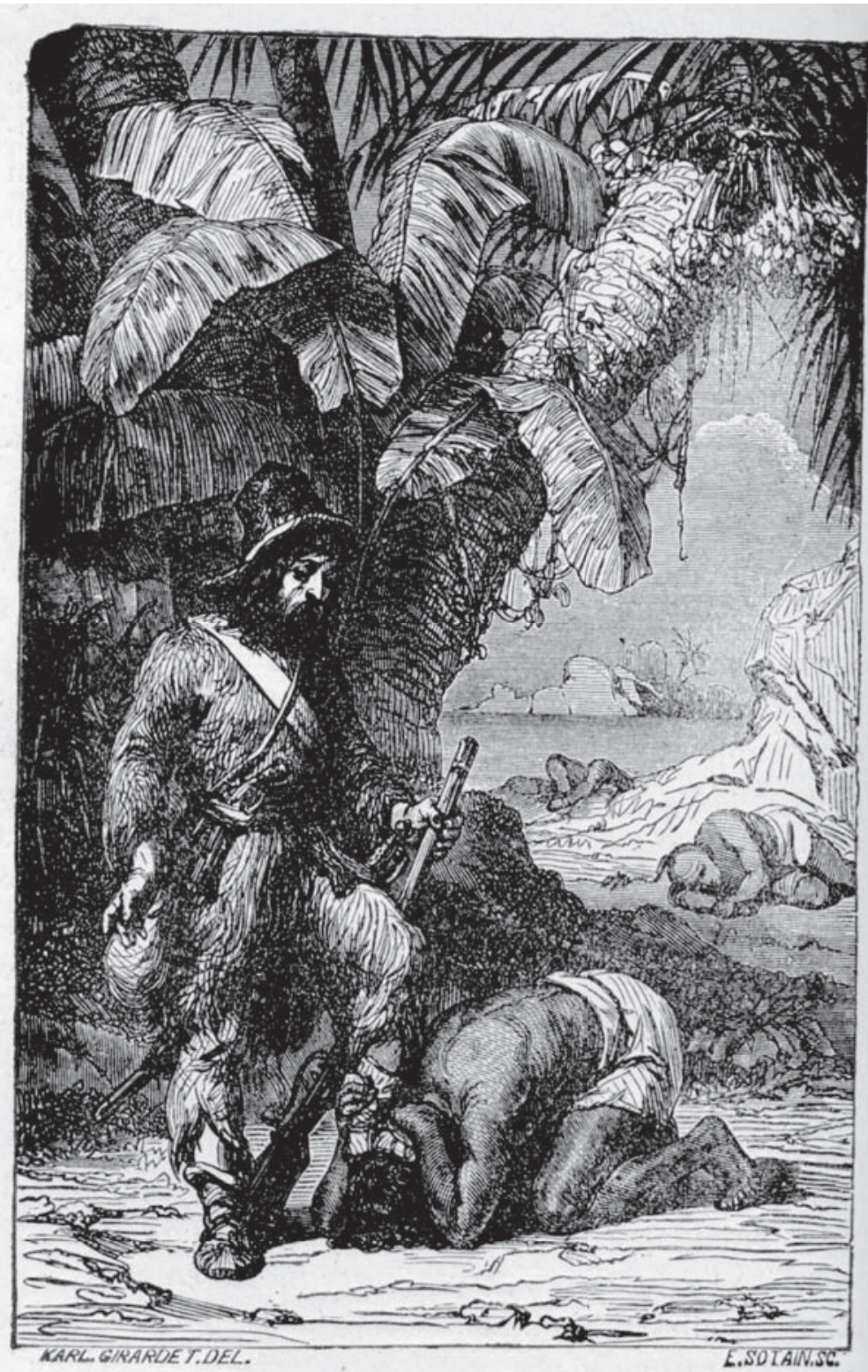

Toma um dos meus pés e o põe sobre a sua cabeça.

Figura 8: Ilustração da Livraria Garnier, Rio de Janeiro, s.d., traduzida do original inglês, p.248. 


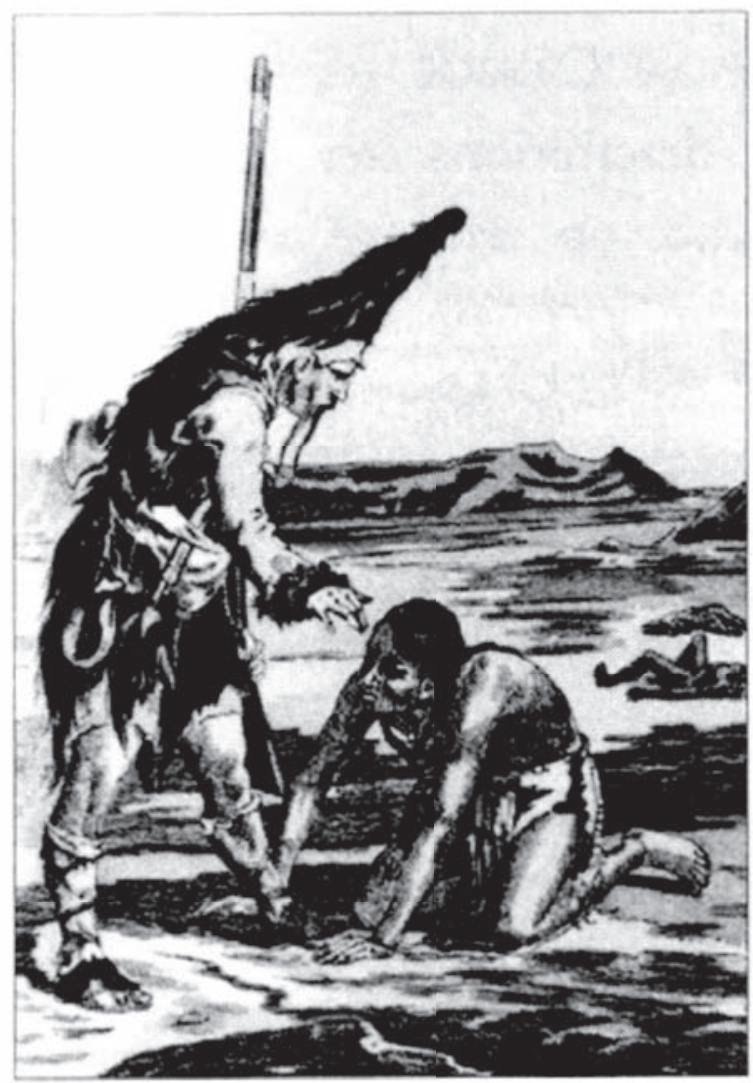

\section{Illustration de L. Nehlig Éd. Garnier frères - vers 1924}

Figura 9: Edição publicada em Paris, pela editora Garnier, por volta de 1924, com ilustração de I. Nehlig. Fonte: Delmas e Meunier (1995).

Quase ao final da história, chega à ilha um grupo de espanhois prisioneiros dos índios que se preparam para executá-los. Neste preciso episódio, acontece a perfeita conversão de Sexta-feira à civilização com sua decidida escolha pelos valores ingleses. Robinson permite que Sexta-feira empunhe uma arma de fogo - suprema prova de confiança do inglês - para ajudá-lo a salvar os espanhois, matando os indígenas caribenhos. Ao atirar contra seus 
“irmãos selvagens", Sexta-feira demonstra sua adesão completa à ordem do colonizador branco. Por sua importância, o episódio aparece constantemente nas ilustrações. Na gravura da edição inglesa de 1885, Robinson ampara o espanhol que, como civilizado europeu, veste roupas em contraste com os indígenas nus. Sexta-feira, vestido com as mesmas roupas de peles de cabra está de costas atirando para matar os índios. Como afirma Peter Hulme, o crânio meio enterrado colocado à frente da ilustração funciona como memento anthropophagi, para lembrar porque essas batalhas precisavam ser travadas (Figura 10) ${ }^{14}$. Na edição francesa de 1845, lá está a mesma composição da cena; enquanto Robinson conforta um espanhol ferido, Sexta-feira se encarrega de atirar nos "inimigos", os indígenas (Figura 11) ${ }^{15}$. Em duas edições brasileiras do século XX, os elementos centrais estão presentes com sua simbologia mantida intacta no que concerne às distinções entre civilização e barbárie. Note-se na edição da Garnier que, no primeiro plano à esquerda, há uma cabeça cortada de europeu e alguns ossos humanos para indicar a justeza da causa dos brancos (Figuras 12 e 13) ${ }^{16}$.

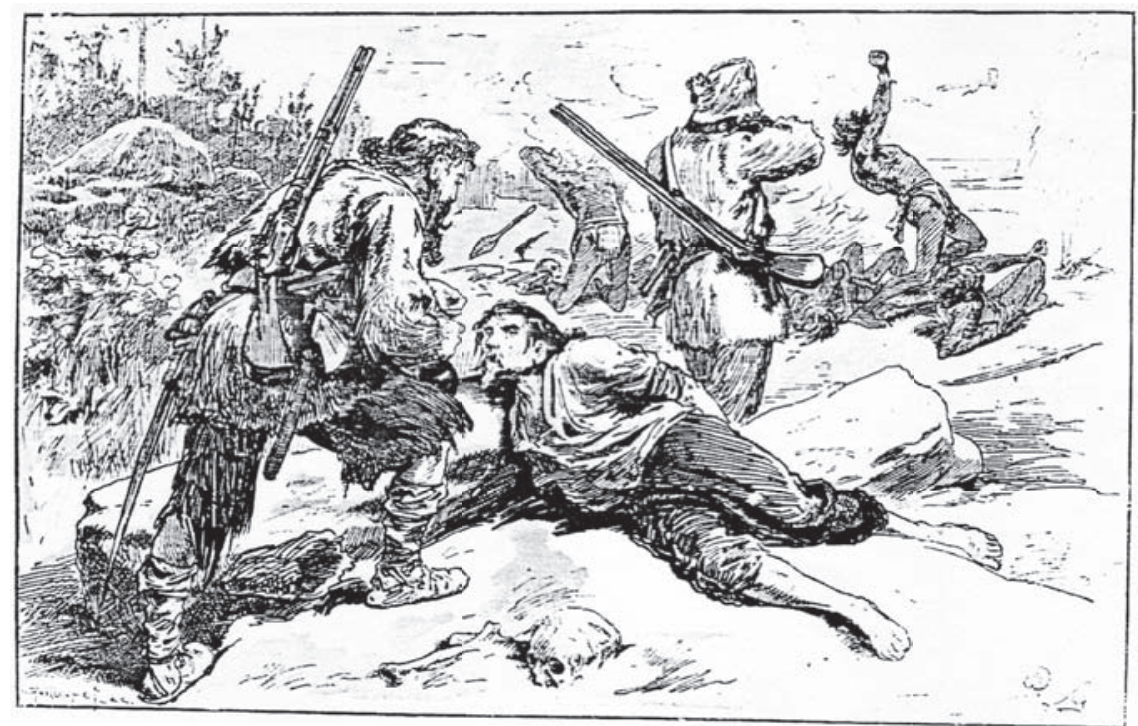

Figura 10: Reproduzido da imagem do texto de Peter Hulme, "Robinson Crusoe", Fonte: Colonial encounters... (1986, p.74). 


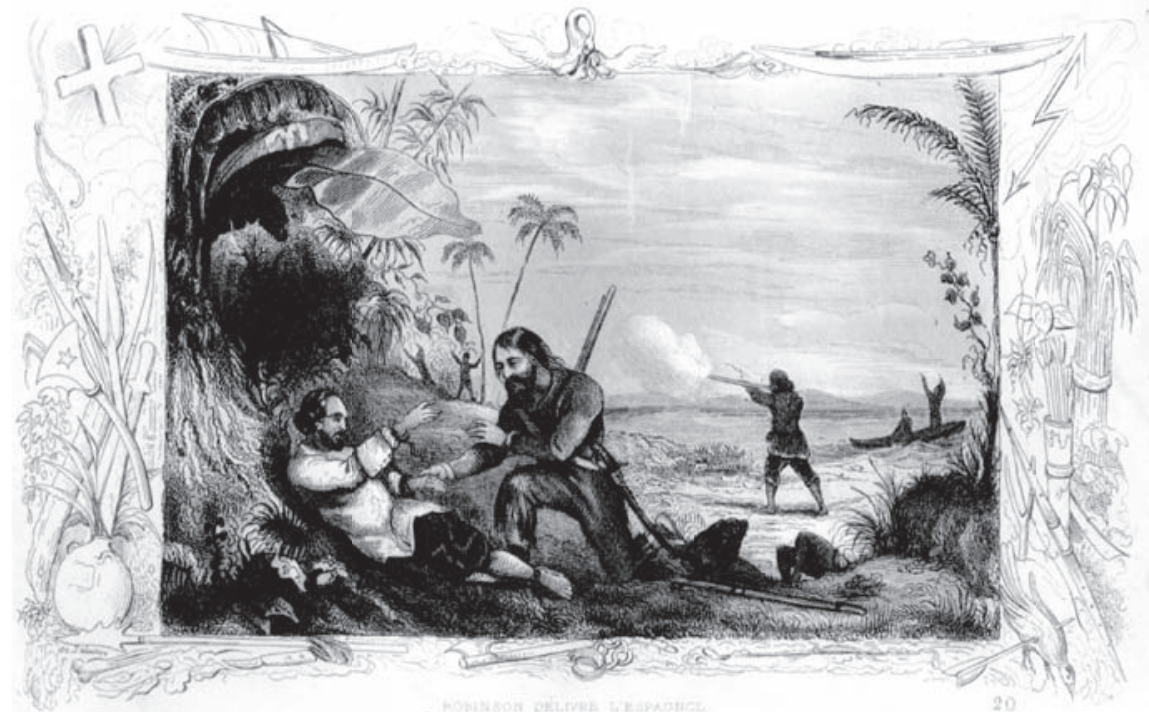

Figura 11: Paris: Didier, Libraire-Éditeur, Edição de 1845.

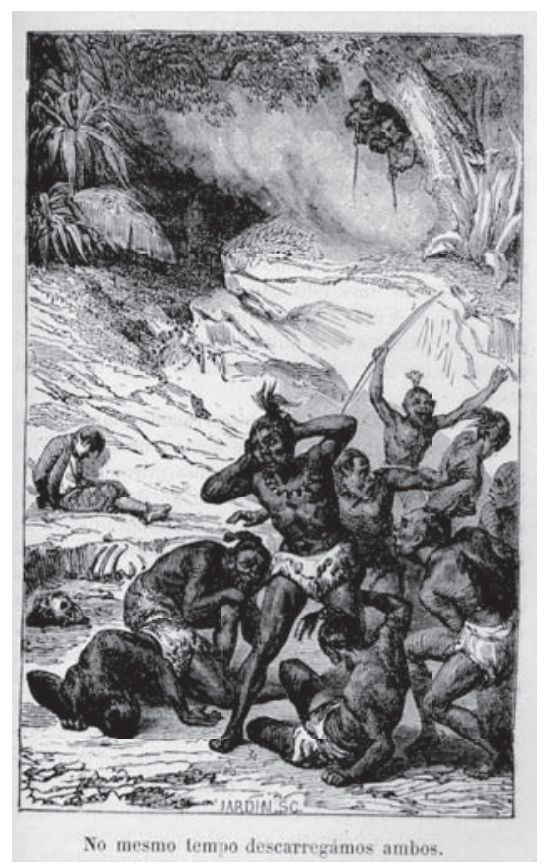

Figura 12: Ilustração da primeira edição publicada no Rio de Janeiro Livraria Garnier, s.d. (já citada), p. 239. 


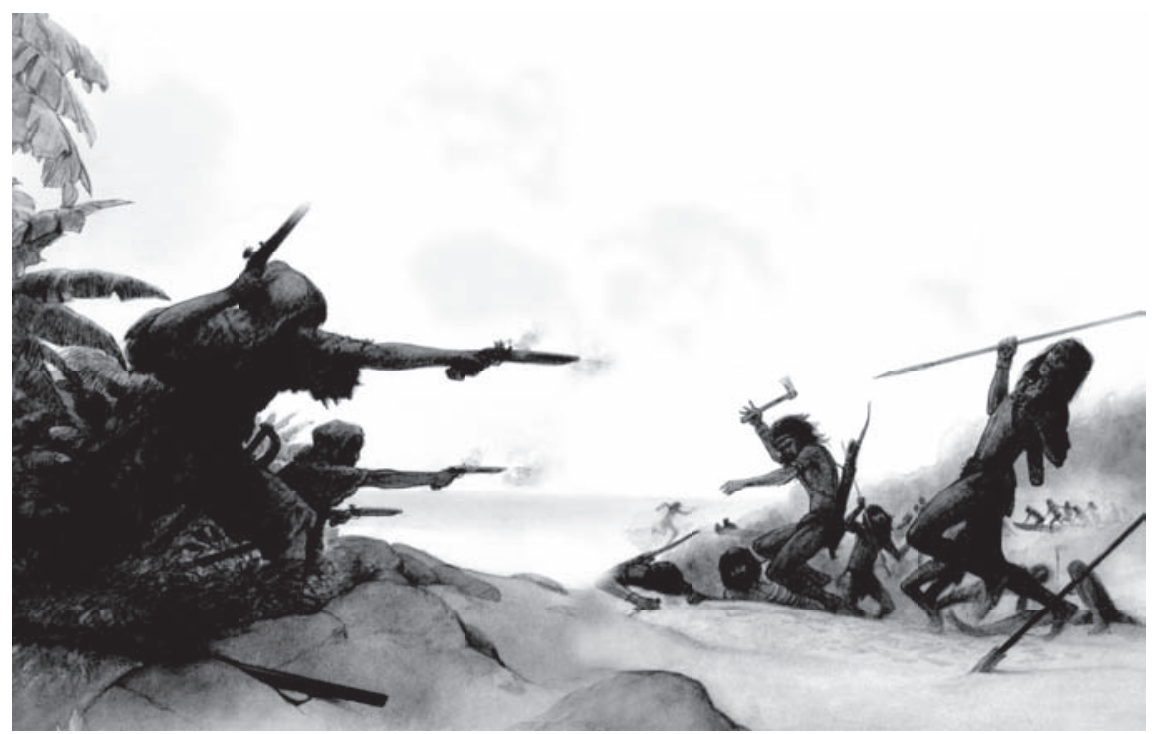

Figura 13: Edição publicada em São Paulo, Companhia das Letrinhas (1999, p. 52 e 53)

Nota: Foi traduzida da edição inglesa publicada em 1998 pela Dorling Kindersley Limited.

É manifesta a vitalidade da fábula do homem solitário vivendo na ilha deserta, pois suas constantes releituras indicam sua sempre renovada atualidade. Livros e filmes revisitam a narrativa. Curioso é lembrar que há até mesmo uma "versão espacial" da história, Robinson Crusoe em Marte, filme de ficção científica de 1964, em que Crusoe salva Sexta-feira (sempre semi-nu) de alienígenas ${ }^{17}$.

Fiz referência anteriormente ao fato do esquecimento do lugar - o mar do Caribe - onde a saga de Robinson Crusoe e Sexta-feira se desenrola. Este não-lugar, aliado à possibilidade da suspensão do tempo em que a história acontece, contribuiu para a proliferação de reapropriações do tema. Desse modo, a narrativa foi ganhando uma roupagem mítica - fora do tempo e do espaço. Essa dimensão pode explicar as últimas ilustrações que apresento, indicando as metamorfoses pelas quais passou Sexta-feira. Nas edições do século XVIII, como já foi mostrado, ele é representado como um índio nos seus traços fisionômicos e na cor da pele. Essa representação do bárbaro como índio continuou a ser reproduzida. Veja-se, por exemplo, a recente e já indicada edição brasileira, voltada para o público infantil, na qual lá está Sexta-feira no seu formato indígena (Figura 14) ${ }^{18}$. Interessante 
também é apresentar a caracterização de Sexta-feira na edição brasileira de 1884, na qual ele está semi-nu, mas ostenta penas coloridas na cabeça, numa imagem que lembra as representações do indígena do Brasil. $\mathrm{O}$ texto foi redigido "para a mocidade brasileira" por Carlos Jansen, do Colégio D. Pedro II (Figura 15) (DEFOE, 1884).

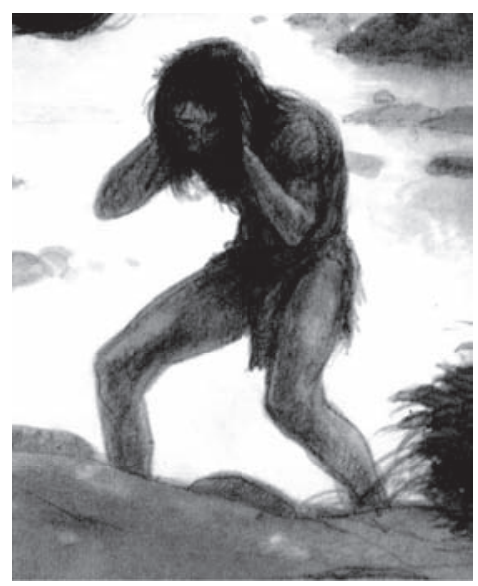

Figura 14: Edição (já citada) publicada em São Paulo, Companhia das Letrinhas (1999, p. 49).

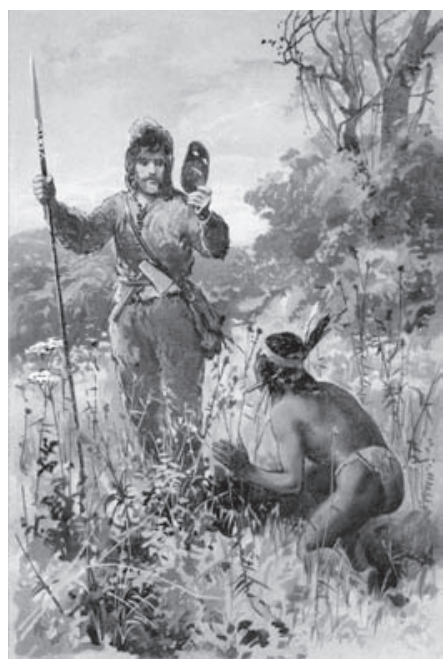

Figura 15: Edição publicada no Rio de Janeiro por Laemmert \& Cia. EditoresProprietários em 1884 
Entretanto, há uma fundamental transformação do "selvagem" índio em "selvagem" negro africano, a partir de algumas edições do século XIX. Essa alteração nos contornos da figura modelar do colonizado vai se processando de maneira paulatina. Na edição francesa de 1845, a pele de Sexta-feira assume um tom mais escuro a ponto de poder ser confundido com um africano (Figura 16) ${ }^{19}$. O mesmo acontece com os índios na já identificada gravura da edição brasileira da Garnier do século XX (Figura 12) ${ }^{20}$. Mas a transformação inequívoca ocorre em edição francesa do começo do século XX: Sexta-feira foi plenamente transfigurado em negro africano (Figura 17) (DELMAS; MEUNIER, 1995). Diante de um Robinson cuja vestimenta consiste em "calças" de pele de cabra e casaco próprio de uniforme militar europeu, ajoelha-se um negro africano semi-nu, estendendo os braços, com as palmas das mãos voltadas para cima, numa atitude de submissão. Desse modo, a ilustração carrega os traços de uma visão colonialista europeia num tempo em que a Europa precisava encontrar justificativas para a intervenção na África. Tal transformação foi apropriada pela edição brasileira da Editora Itatiaia de 1964, que integra a Coleção Clássicos da Juventude. Na capa, está Sexta-feira pintado como um negro africano com lábios grossos e cabelos crespos; eles estão atravessados por ossinhos, associando - de forma equivocada - a África ao canibalismo (Figura18) ${ }^{21}$. Se entrarmos aleatoriamente na internet em busca de representações de Sexta-feira, encontraremos imagens de um negro africano, mostrando a permanência dessa imprópria assimilação (Figura19).

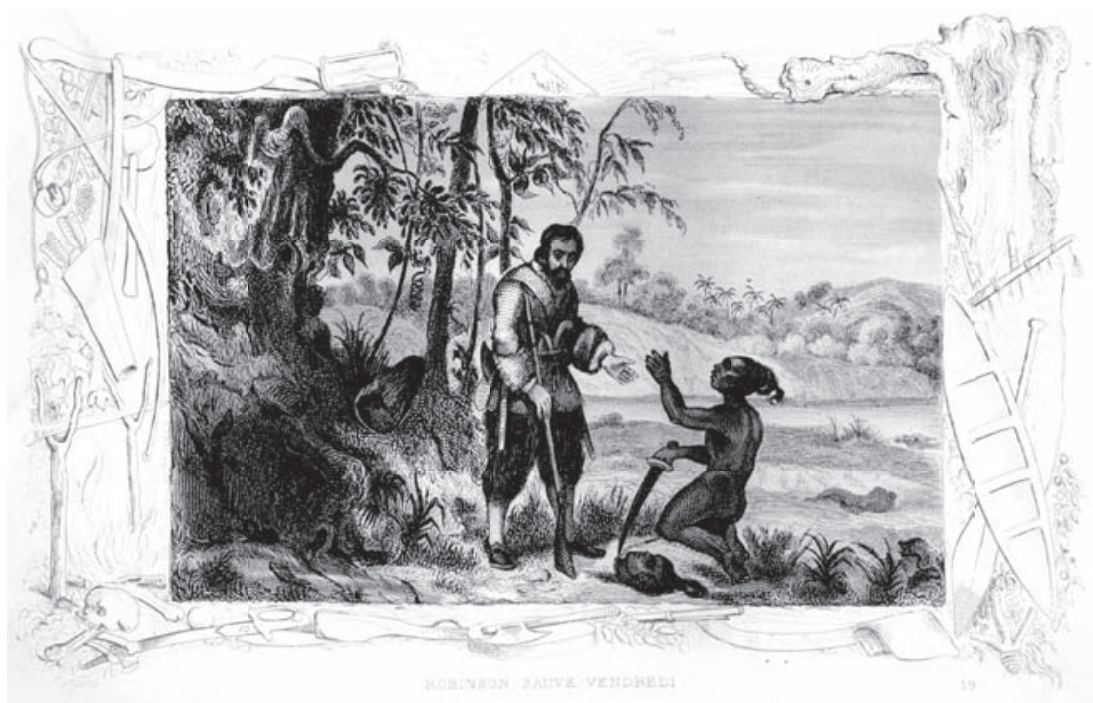

Figura 16 : Edição francesa.Paris, Didier, Libraire-Éditeur, 1845. 


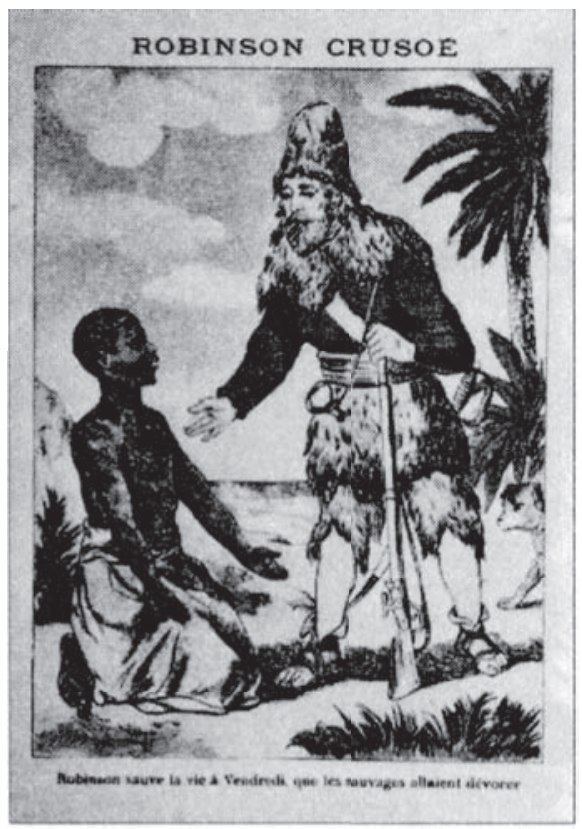

Album anonyme - Début $x^{e}$ siècle

Figura 17: Ilustração Estraída de M-Charlotte Delmas \& Jacques Munier. Les Aventures de Robinson Crusoe (1995, p. 40).
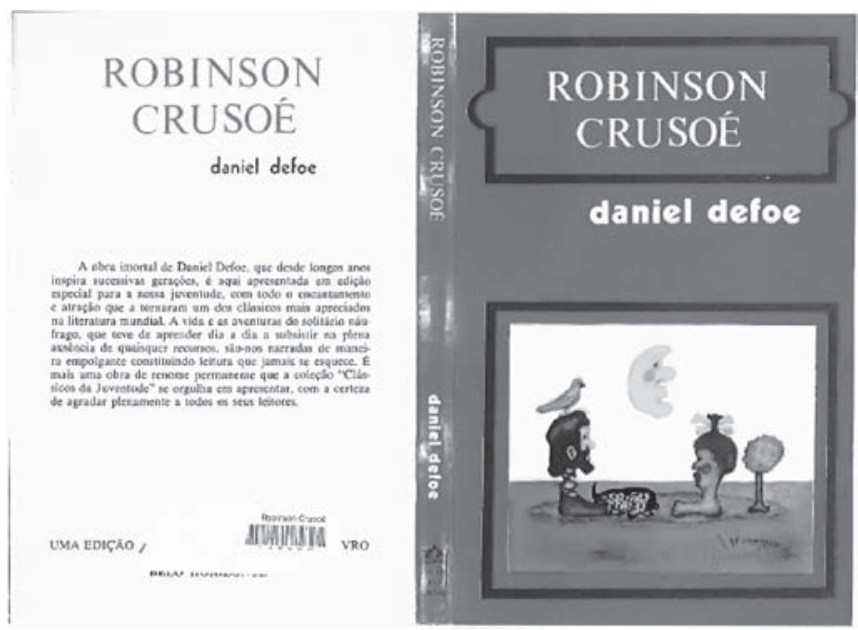

Figura 18: Capa e contracapa da edição publicada pela Editora Itatiaia de Belo Horizonte, em 1964. Coleção Clássicos da Juventude. 


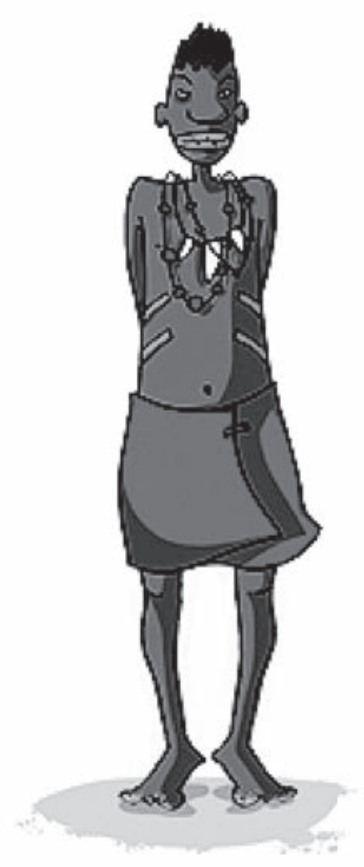

Figura 19: Sexta-Feira.

Fonte:<http://1.bp.blogspot.com/_yEE_GL-q3ho/SbRj8evlpRI/AAAAAAAAAVY/dybxE5vtpWo/s400/ home.gif $>$. Acesso em: 12 mar. 2010.

As apropriações e adaptações da história original de Robinson Crusoe e Sexta-feira carregam fortes significados culturais e políticos, que se renovam até o presente. A história do inglês náufrago no Caribe oferece elementos que permitem releituras e contribuem para sutilmente defender a lógica da superioridade da "civilização" sobre a "barbárie" e justificar o encontro assimétrico entre colonizador e colonizado, em qualquer época da História. O olhar imperial se manifesta naturalizando essa relação e ocultando sua violência ${ }^{22}$.

Nos diálogos culturais entre o Velho e o Novo Mundo, no alvorecer dos tempos modernos, a saga de Robinson Crusoe e Sexta-feira desponta como texto referencial, por sua simplicidade, sua pretensa neutralidade e sua contundente formulação da possibilidade da construção de uma relação harmoniosa e ingênua entre colonizador e colonizado. 
Dialogues between the old and the new world Robinson Crusoe and Friday

Aвstract: The novel, Life and Adventures of Robinson Crusoe, written by Daniel Defoe, was published in 1719 and immediately became a bestseller. The book had many editions and the illustrations of the main characters, Robinson Crusoe and Friday, changed throughout the times. This article intends to discuss these different images and their interpretations, considering that Defoe's narrative evokes a naturalized relationship between the colonialist and the colonized.

Keywords: Crusoe, Friday, Defoe, civilization, barbarism.

\section{NOTAS}

1 Para a leitura do romance, utilizei as edições com texto completo. Defoe (1955; 1965).

2 O navio em que Selkirk viajava acabou naufragando e matando toda a tripulação.

3 A ideia da solidão absoluta, da vida apartada da sociedade, parece ter sempre povoado a imaginação ocidental. Na Idade Média, narrativas de ermitões que escolhem o isolamento são inúmeras. Lembro aqui a versão de Thomas Mann sobre a vida lendária de São Gregório: depois de cometer "terríveis pecados", o santo retira-se para uma ilha deserta, onde deve se purificar através da penitência e do sofrimento para alcançar o perdão de suas faltas (MANN, 1972).

4 Fenômeno semelhante aconteceu com o romance para adultos de Jonathan Swift, As Viagens de Gulliver, publicado em 1726, e traduzido para o francês, em 1727, pelo abade Desfontaines.

5 Essas imagens foram retiradas das seguintes edições: Londres: W. Taylor, 1719; Amsterdam: L'Honoré \& Chatelais, 1720, ilustração de Bernard Picard; Paris: Fournier Aïné, 1840, ilustração de Grandville; Paris: Bovin \&Cie., ilustração de Valentin Lê Campion in Delmas, Marie-Charlotte \& Meunier, Jacques. Les Aventures de Robinson Crusoe: parcours éditorial d'une oeuvre littéraire. Issy-les-Moulineaux : Association d'Animation de la Médiathèque d'Issy-lesMoulineaux, 1995. E a edição brasileira: Robinson Crusoe: Aventura de um náufrago numa ilha deserta. São Paulo: Companhia das Letrinhas, 1999.

6 Ver alguns textos clássicos como Novak (1963) e Starr (1965).

7 Não nos esqueçamos que no romance, quando Robinson regressa à Inglaterra, descobre que está rico, porque suas rendas deixadas nas mãos de pessoas honestas fizeram multiplicar seu capital, mostrando como o capitalismo recompensa aqueles que poupam.

8 É interessante lembrar que Karl Marx utilizou Robinson Crusoe como exemplo 
para, no primeiro tomo de $O$ Capital, mostrar a diferença entre produção para uso e produção para troca e valor de uso e valor de troca.

9 Cf. Joyce (1964, p. 24). O texto de Joyce continua: “O completo espírito anglosaxão está em Crusoe: a masculina independência; a crueldade inconsciente; a persistência; a lenta mas eficiente inteligência; a apatia sexual; a religiosidade equilibrada e prática; a calculada taciturnidade."

10 Para uma visão oposta à de Defoe sobre a relação entre Robinson e Sexta-feira, ver Tournier, Michel, Sexta-feira ou os limbos do Pacífico, Rio de Janeiro: Difel,1985. Tournier faz parte da geração vinculada aos movimentos culturais de 1968, na França. No romance, depois de muitas peripécias, Robinson - cuja ilha explodiu porque Sexta-feira inadvertidamente jogou seu cachimbo aceso na pólvora guardada - revê seus valores e suas crenças e começa a aprender com Sexta-feira a viver de outro modo. No fim da história, Robinson se recusa a voltar para a civilização, enquanto Sexta-feira deslumbrado com a técnica moderna (por exemplo, os mastros do navio) embarca. Seu fim será a escravização.

11 A edição não tem data, mas é do século XVIII por todas as características da publicação. Foi publicada em Londres por S. Jewkes (p.75). Integra a Opie Collection of Children's Literature que se encontra na Bodleian Library da Universidade de Oxford.

12 É uma edição produzida no Rio de Janeiro, da Livraria Garnier, s.d., traduzida do original inglês; a imagem está na p.248.

13 Edição publicada em Paris, pela editora Garnier, por volta de 1924, com ilustração de I. Nehlig, retirada de Delmas (1986, p. 74).

14 Reproduzido da imagem do texto de Hulme (1986, p. 74).

15 Paris: Didier, Libraire-Éditeur, 1845.

16 A primeira edição já citada foi publicada no Rio de Janeiro: Livraria Garnier, s.d., p.239; a segunda é de São Paulo: Companhia das Letrinhas, 1999, pp. 52 e 53.

17 Impressiona o número de filmes que têm Robinson Crusoe como protagonista. Tomando alguns pouco exemplo, começo pelo dirigido por Luis Buñuel - Robinson Crusoe, de 1952 - que mostra uma visão absolutamente tradicional, sem qualquer perspectiva crítica da relação colonizador/colonizado. Lina Wertmüller - Por um Destino Insólito (1974) - produz um filme extremamente interessante sobre as relações entre as classes sociais, entre uma patroa burguesa e seu criado, náufragos numa ilha deserta. O recente filme de Robert Zemeckis - Náufrago (2000) - conta a mesma história da luta do indivíduo solitário para conseguir sua sobrevivência apoiado em seus conhecimentos e habilidades racionais. Para mim, o mais revelador é que o náufrago elege uma bola - vale dizer, uma mercadoria - como sua única companhia. 
18 Cf. Defoe (1999, p. 49) Foi traduzida da edição inglesa publicada em 1998 pela Dorling Kindersley Limited.

19 Paris: Didier, Libraire-Éditeur, 1845.

20 Rio de Janeiro: Livraria Garnier, s.d., traduzida do original inglês.

21 Belo Horizonte: Editora Itatiaia, 1964, Coleção Clássicos da Juventude.

22 Numa perspectiva bastante crítica com relação à colonização e ao eurocentrismo, 0 escritor sul-africano J. M. Coetzee escreveu sua versão da saga de Robinson Crusoe, que não é a personagem principal, morrendo no início do romance. Sexta-feira é seu escravo negro cuja língua foi cortada. Robinson é um preguiçoso que não trabalha e morre na viagem de volta à Inglaterra. A personagem principal é uma decidida mulher que viajara à Bahia em busca da filha perdida. Ela naufraga e encontra Robinson e Sexta-feira em uma ilha e com eles volta à Inglaterra. Com a morte de Robinson, sente-se responsável por Sexta-feira, mas não sabe o que fazer com ele. O livro é desesperançado e não propõe qualquer solução para os dilemas vividos pelos personagens. CoETZEE, J. M. Foe. Nova York: Viking, 1987.

\section{REFERÊNCIAS}

COETZEE, J. M. Foe. Nova York: Viking, 1987.

COLONIAL Encounters: Europe and the native Caribbean, 1492-1797. Londres e Nova York: Methuen, 1986.

DEFOE, Daniel. Vida e aventuras de Robinson Crusoe. São Paulo: Clube do Livro, 1955.

. Robinson Crusoe. Nova York: Penguin Books, 1965.

DELMAS, Marie-Charlotte; Meunier, Jacques. Les Aventures de Robinson Crusoe: parcours éditorial d'une ceuvre littéraire. Issy-les-Moulineaux : Association d'Animation de la Médiathèque d'Issy-les-Moulineaux, 1995.

. Les Aventures de Robinson Crusoe: parcours éditorial d'une oeuvre littéraire. Issy-les-Moulineaux: Association d'Animation de la Médiathèque d'Issy-lesMoulineaux, 1995.

HILL, Christopher. Robinson Crusoe. History Workshop Journal, Oxford: Oxford University Press, 1972.

HULME, Peter. Colonial Encounters: Europe and the native Caribbean, 1492-1797. Londres, Nova York: Methuen, 1986.

. Robinson Crusoe. Colonial Encounters: Europe and the native Caribbean, 1492-1797. Londres e Nova York: Methuen, 1986.

HYMER, Stephen. Robinson Crusoe and the secret of primitive accumulation. Monthly Review, Sept. 1971. 
JOYCE, James. Daniel Defoe. Buffalo Studies, I, Nova York: Buffalo, 1964.

MANN, Thomas. O eleito. Lisboa: Publicações Europa-América, 1972.

NOVAK, M. E. Defoe and the Nature of Man. Oxford: Oxford University Press, 1963;

NOVAK, M. E. Economics and the Fiction of Daniel Defoe. Berkeley: University of California Press, 1962.

ROUSSEAU, Jean-Jacques. Emílio ou Da Educação. São Paulo: M. Fontes, 2004.

STARR, G. A. Defoe and Spiritual Autobiography. Princeton: Princeton University Press, 1965.

SWIFT, Jonathan. As viagens de Gulliver. Porto Alegre: LP\&M, 2005.

TOUNIER, Michel. Sexta-feira ou os limbos do Pacifico. Rio de Janeiro: Bertrand Brasil, 1995.

WATT, Ian. The rise of the novel: studies in Defoe, Richardson and Fielding. Londres: Chatto and Windus, 1957. 
